\title{
Sitosterol and cholesterol in chylomicrons of type 2 diabetic and non-diabetic subjects: the relationship with ATP binding cassette proteins G5 and G8 and Niemann-Pick C1-like 1 mRNA
}

\author{
S. E. Lally • D. Owens • G. H. Tomkin
}

Received: 21 July 2006 / Accepted: 28 September 2006 / Published online: 11 November 2006

(C) Springer-Verlag 2006

To the Editor: The dyslipidaemia of diabetes is in part related to a disturbance in genes regulating cholesterol absorption and excretion [1]. Sitosterolaemia is associated with increased atherosclerosis [2]. The higher the absorption of cholesterol, the more plant sterol is found in the atherosclerotic plaque [3]. The intestinal cholesterol transporter, Niemann-Pick C1-like 1 (NPC1L1), regulates cholesterol absorption and NPC1L1 mRNA is increased in type 2 diabetic patients [4]. ATP binding cassette proteins (ABC) G5 and G8 regulate cholesterol homeostasis by reexcreting some of the cholesterol and most of the plant sterols from the enterocyte back into the intestinal lumen [2]. Patients with diabetes have decreased $A B C G 5$ and $G 8$ mRNA expression [1]. In diabetes, chylomicron cholesterol is increased. Absorbed plant sterols that enter the circulation are rapidly re-excreted directly into the bile rather than being converted to bile salts. Thus abnormalities in plant sterol absorption may not be detected by examining serum in the fasting state. Foods enriched with plant sterol are being promoted to prevent atherosclerosis. However, the amount needed is more than five times the normal dietary plant sterol intake (0.3-0.4 g/day) and there are no endpoint studies to confirm benefit. Our aim was to examine the effect of a sitosterol-enriched diet on chylomicron compo-

\footnotetext{
S. E. Lally $\cdot$ D. Owens $\cdot$ G. H. Tomkin

Department of Diabetes and Endocrinology,

Trinity College Dublin,

Dublin, Ireland

G. H. Tomkin $(\bowtie)$

Diabetes Research Foundation, Clontra,

Quinns Road, Shankill Co,

Dublin, Ireland

e-mail: gerald.tomkin@tcd.ie
}

sition and to examine the relationship between chylomicron sitosterol and intestinal $A B C G 5$ and G8 and NPC1L1 gene expression.

Six type 2 diabetic patients (two male, four female; age $63.8 \pm 3.4$ years, BMI $29.5 \pm 5.6 \mathrm{~kg} / \mathrm{m}^{2}, \mathrm{HbA}_{1 \mathrm{c}} 6.6 \pm 1.1 \%$ $[$ means $\pm \mathrm{SD}]$ ) and six control subjects of similar age (three male, three female, age $63.3 \pm 4.8$, BMI $26.8 \pm 2.0 \mathrm{~kg} / \mathrm{m}^{2}$ ), none of whom were on statin treatment, were studied. All subjects gave informed consent and the study was approved by the hospital ethics committee. Two of the diabetic patients were treated with diet alone, two with metformin, one with metformin and rosiglitazone, and one with gliclazide. All subjects had previously had duodenal biopsies when undergoing routine gastroscopy for non-specific abdominal symptoms. Subjects with cancer, inflammatory bowel disease and coeliac disease or previous gastric operations were excluded. All subjects were given 1 week of a sitosterol-enriched diet (2.5 g/day), in which sitosterolenriched margarine and milk or yogurt were substituted for their normal dairy products. On the day of the study all subjects had fasting blood taken followed by a $4.60 \mathrm{MJ}$ $(1,100 \mathrm{kcal})$ high-fat test meal containing $2.0 \mathrm{~g}$ sitosterol. Blood was sampled at 4 and $6 \mathrm{~h}$ following the meal.

Chylomicrons were isolated from plasma by ultracentrifugation. Apolipoprotein (Apo) B48 and Apo B100 were determined by gradient gel electrophoresis and quantified by densitometry [2]. Chylomicron cholesterol and sitosterol were determined by gas chromatography and identified using mass spectrometry. NPC1L1, and $A B C G 5$ and $A B C G 8$ mRNA were determined by TaqMan assay and quantified (arbitrary units, AU) by reference to GAPDH [2].

Fasting serum cholesterol for diabetic and control subjects was $5.0 \pm 0.9$ and $4.7 \pm 1.1 \mathrm{mmol} / \mathrm{l}$, respectively, and mean plasma triacylglycerol was $1.6 \pm 0.7$ vs $2.1 \pm 1.3 \mathrm{mmol} / \mathrm{l}$, 

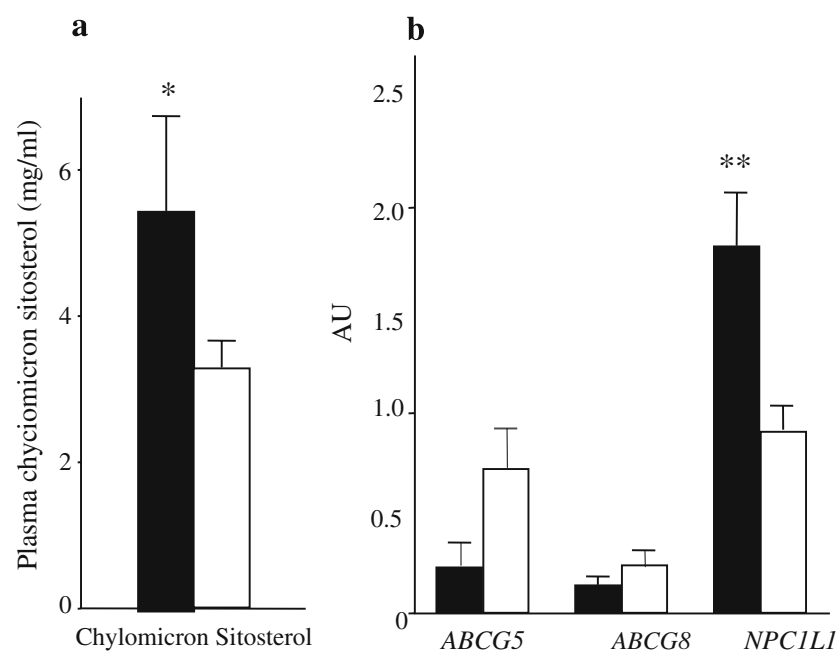

Fig. 1 a Chylomicron sitosterol in diabetic (solid bar) and nondiabetic subjects (open bar). Asterisk: $p<0.02$ compared with nondiabetic. b ABCG5, ABCG8 and NPC1L1 mRNA expression in intestinal biopsies from diabetic (solid bars) and non-diabetic subjects (open bars). Double asterisks: $p<0.002$ compared with control subjects

median 1.4 vs 1.3 , range $0.7-2.2$ vs $1.0-3.9 \mathrm{mmol} / \mathrm{l}$. Postprandial chylomicron sitosterol was significantly increased in diabetic patients $(5.5 \pm 1.2$ vs $3.4 \pm 1.3 \mathrm{mg} / \mathrm{ml}$ plasma, $p<0.02$ ) (Fig. 1). Postprandial chylomicron cholesterol was $5,530 \pm 1,844 \mathrm{mg} / \mathrm{ml}$ plasma in the diabetic patients vs $2,561 \pm 1,444 \mathrm{mg} / \mathrm{ml}$ plasma for control subjects. There was a positive correlation between chylomicron sitosterol and chylomicron cholesterol in the combined group $(r=0.80$, $p<0.001)$. Chylomicron Apo B48 was $18.4 \pm 9.3$ vs $7.5 \pm$ $4.1 \mu \mathrm{g} / \mathrm{ml}$ plasma $(p<0.02)$ and Apo B100 was $3.4 \pm 0.9$ and $1.7 \pm 0.8 \mu \mathrm{g} / \mathrm{ml}$ plasma $(p<0.005)$ for diabetic and control subjects, respectively. $A B C G 5 \mathrm{mRNA}$ at $0.21 \pm 0.09$ vs $0.67 \pm$ 0.71 and $A B C G 8$ at $0.13 \pm 0.11$ vs $0.24 \pm 0.47$ AU were lower in diabetic patients and NPC1L1 mRNA was significantly higher in the diabetic patients $(0.97 \pm 0.34$ vs $1.93 \pm 0.47 \mathrm{AU}$, $p<0.002$ ) (Fig. 1). There was a positive correlation between sitosterol and NPC1L1 mRNA $(r=0.54, p<0.05)$.

Although phytosterol-enriched foods are promoted as being helpful in preventing atherosclerosis through the $10 \%$ lowering of cholesterol, there are no endpoint studies to confirm benefit. Most type 2 diabetic patients are overweight or obese and to ingest $2.5 \mathrm{~g}$ of sitosterol (the recommended dose to lower cholesterol) approximately $1.26 \mathrm{MJ}(300 \mathrm{kcal})$ must be ingested daily. The chylomicron particle is relatively poor in sterol content compared with LDL, but the ability to transport sterols is enormous due to its rapid turnover, explaining the atherogenicity of these particles. Our study demonstrates a significant increase in sitosterol in diabetic patients and a relationship between NPC1L1 mRNA and sitosterol resulting in the significant correlation between chylomicron sitosterol and cholesterol that we found. Although the diabetic patients had reduced $A B C G 5$ and $G 8$ mRNA the reduction did not quite reach significance, but in a previous study we have shown that diabetic patients have significantly lower levels than controls [3]. Thus it is probable that both the increased NPC1L1 and the lower ABCG5/G8 led to the increase in cholesterol and sitosterol that we found in the chylomicron particle in the diabetic patients [2]. Miettinen et al. [3] have shown that the higher the absorption of cholesterol the higher is the plant sterol content of serum and atherosclerotic plaques, which they studied following carotid endarterectomy. In that study, in which they divided the plaques into high, medium and low cholesterol, the low cholesterol plaques had the highest non-cholesterol sterols. Sitosterolaemia, associated with gene polymorphisms of $A B C G 5$ and $G 8$ is known to be associated with severe atherosclerosis [2]. Since 1991 [5] reports have suggested that raised serum plant sterols are a risk factor for coronary artery disease. A recent report from the Prospective Cardiovascular Munster (PROCAM) study [6] demonstrated raised phytosterols to be an independent risk factor for coronary artery disease. The association was not confirmed in the Dallas Study [7], but only fasting serum levels were measured. The majority of absorbed plant sterols are carried in the chylomicron particle and rapidly excreted in the bile, hence fasting serum levels may not reflect the postprandial state, particularly in diabetes.

This study demonstrates that the addition of $2.5 \mathrm{~g}$ /day of sitosterol to the diet results in a significant elevation of chylomicron sitosterol in diabetic patients compared with controls on a similar diet. This is a very small study carried out using an experimental meal but if the results are confirmed in a larger study of free-living patients the longterm benefit of dietary sitosterol supplementation would need to be evaluated before sitosterol-enriched foods can be safely recommended to diabetic patients.

Acknowledgements The authors wish to thank D. Neely for his helpful comments and M. Pourfarzam (Royal Victoria Infirmary, Newcastle-upon-Tyne, UK) for measurement of chylomicron sitosterol.

\section{References}

1. Lally S, Tan CY, Owens D, Tomkin GH (2006) mRNA levels of genes involved in dysregulation of postprandial lipoproteins in type 2 diabetes: the role of Niemann Pick C1-like 1, ABCG5 and G8 and microsomal triglyceride transfer protein. Diabetologia 49:1008-1016

2. Berge KE, Tian H, Graf GA et al (2000) Accumulation of dietary cholesterol in sitosterolemia caused by mutations in adjacent $\mathrm{ABC}$ transporters. Science 290:1771-1775

3. Miettinen TA, Railo M, Lepantalo M, Gylling H (2005) Plant sterols in serum and in atherosclerotic plaques of patients undergoing carotid endarterectomy. J Am Coll Cardiol 45:1794-1801 
4. Altmann SW, Davis HR Jr, Zhu LJ et al (2004) Niemann-Pick C1 like 1 protein is critical for intestinal cholesterol absorption. Science 303:1201-1204

5. Glueck CJ, Speirs J, Tracy T, Streicher P, Illig E, Vandegrift J (1991) Relationships of serum plant sterols (phytosterols) and cholesterol in 595 hypercholesterolemic subjects, and familial aggregation of phytosterols, cholesterol, and premature coronary heart disease in hyperphytosterolemic probands and their firstdegree relatives. Metabolism 40:842-848
6. Assmann G, Cullen P, Erbey J, Ramey DR, Kannenberg F, Schulte H (2006) Plasma sitosterol elevations are associated with an increased incidence of coronary events in men: results of a nested case-control analysis of the Prospective Cardiovascular Munster (PROCAM) study. Nutr Metab Cardiovasc Dis $16: 13-21$

7. Wilund KR, Yu L, Xu F et al (2004) No association between plasma levels of plant sterols and atherosclerosis in mice and men. Arterioscler Thromb Vasc Biol 24:2326-2332 